\title{
Termografi ved frostskader i Forsvaret
}

\author{
I 2013 registrerte Forsvaret 143 personer med perifere frostskader, og oppmerksomheten rundt militær \\ opplæring i mestring av kulde er økt. Vi ønsker nå å bruke infrarøde varmekameraer for å identifisere \\ soldater med særskilt risiko samt til diagnostikk av frostskader.
}

Et varmekamera danner termogrammer av hudens varmestråling som avhenger av blodsirkulasjon i de ytterste millimeterne av huden, en blodstrøm underlagt komplisert regulering via nervesystem, humorale mekanismer og lokale faktorer. Ved Universitetet i Tromsø og Universitetssykehuset Nord-Norge er termografi etablert i forskning og klinisk praksis (1) (fig 1). De siste par tiår er termografi også blitt omtalt som en metode som bør utforskes videre i forhold til diagnostikk og behandling av frostskader (2).

En oversiktsartikkel peker på at termografi øker klinisk diagnostisk sikkerhet ved kulde- og frostskader (3). Også retrospektivt $i$ en lengre horisont har bruken av termografi vært evaluert. Det er her særlig verdt å nevne bruk av termografi i kartlegging av kuldeog frostskader og oppfølging av britiske militære etter Falklandskrigen i 1982 (4).

Termografi har også vært undersøkt med tanke på å avdekke patofysiologi bak sirkulasjonsforstyrrelser som del av årsaksrekken (5). Frostskader kan etterlate forstyrrelser i mikrovaskularisering og reguleringen av denne. Man har funnet at dette kan diagnostiseres med termografi (6). Det er også gjennomført studier for å etablere referanseverdier for bruk av termografi ved forstyrrelser i mikrovaskularisering (7).

I medieoppslag er det tatt til orde for bedre militær opplæring i mestring av kulde.
Hærstaben har nylig nedsatt en tverrfaglig arbeidsgruppe som har utarbeidet bestemmelser, retningslinjer og kompetansegrunnlag for å kunne redusere og forhindre nye tilfeller av nedkjøling og lokale kulde- og frostskader under såkalte mestringsøvelser.

Forsvaret skal i et samarbeid med Universitetet i Tromsø og Universitetssykehuset Nord-Norge unders $ø$ ke om termografi kan gi anvendbar data om perifer sirkulasjon hos vernepliktig personell. Soldater med dårlig mikrosirkulasjon i hender/fingre ved innrykk er av særskilt interesse. Vi håper at termografi før vintertrening kan identifisere risikoindivider for kulde- og frostskader.

\section{Arne Johan Norheim \\ arne.johan.norheim@hlkbb.no \\ James Mercer \\ Louis de Weerd \\ Einar Kristian Borud \\ Terje Sagen \\ Dag Hjelle}

Arne Johan Norheim (f.1961) er spesialist i allmennmedisin ved Vitalisklinikken i Harstad, seniorforsker/ph.d. ved Nasjonalt forskningssenter innen komplementær og alternativ medisin, avdelingslege ved Trondenes/Forsvarets sanitet og leder for forskningsprosjektet Termografi ved frostskader i Forsvaret. Forfatter har fylt ut ICMJE-skjemaet og oppgir ingen interessekonflikter.
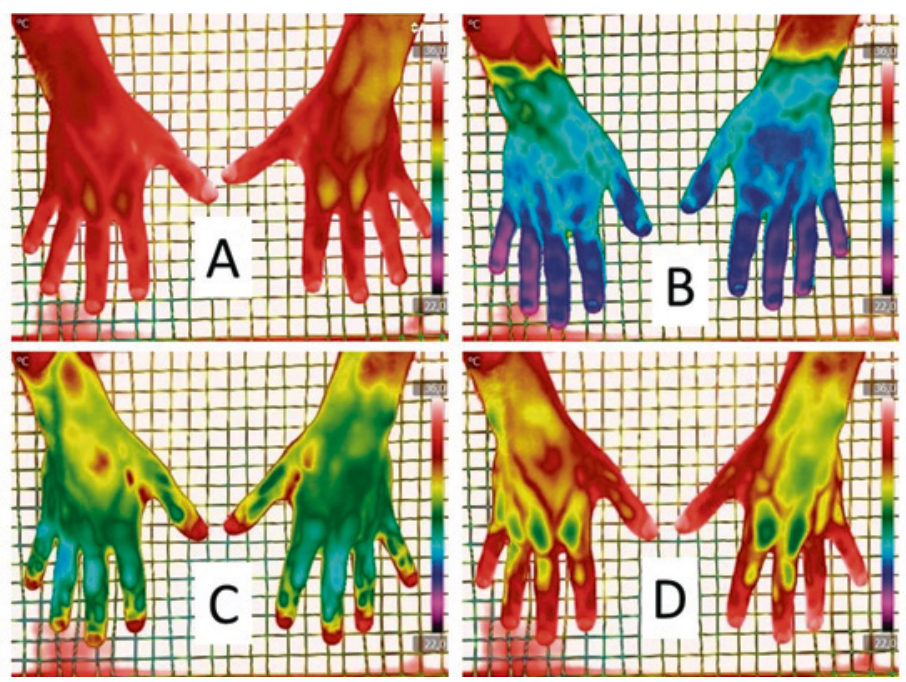

Figur 1 a) Normalt termografi av hendene hos en frisk soldat. Dorsalsiden av hånd avgir en normal varmestråling som ligger over $30^{\circ} \mathrm{C}$, fingrenes dorsalside vanligvis rundt $35^{\circ} \mathrm{C}$. b) Ved dynamisk termografi foretas en nedkjøling der hånden kjøles ned i 1 minutt i $20^{\circ} \mathrm{C}$ vann. Umiddelbart etter endt nedkjøling har fingrenes dorsalside en overflatetemperatur rundt $23-25^{\circ} \mathrm{C}$. c) Under standardisert oppvarming foretas kontinuerlig varmefotografering. En intakt sirkulasjonsregulering via de arteriovenøse anastomoser vil bidra til at mikrosirkulasjon gjenopprettes i løpet av et par minutter. Oppvarming skjer først distalt i fingrene, tommel først og lillefingre som regel sist. d) Dynamisk termografiundersøkelse vurderes som normal når en definert proporsjon av fingrenes dorsalside har gjenvunnet samme varmestråling som før nedkjøling, vanligvis innen 4-5 minutter

James Mercer (f. 1949) er professor ved Forsk ningsgruppe for medisinsk avbildning, Institutt for klinisk medisin, Universitetet i Tromsø og leder av the European Association of Thermology. Forfatter har fylt ut ICMJE-skjemaet og oppgir ingen interessekonflikter.

Louis de Weerd (f. 1958) er spesialist i plastikkirurgi og overlege ved Plastikkirurgisk avdeling, Universitetssykehuset i Nord-Norge. Forfatter har fylt ut ICMJE-skjemaet og oppgir ingen interessekonflikter.

Einar Kristian Borud (f. 1956) er spesialist i allmennmedisin og i samfunnsmedisin, ph.d. og overlege ved Forsvarets sanitet/Forsvarets helseregister.

Forfatter har fylt ut ICMJE-skjemaet og oppgir ingen interessekonflikter.

Terje Sagen (f. 1959) er militærlege, har jobbet som allmennlege og i Kompetansessenter for informasjonsteknologi i helsevesenet (KITH) og er sjef ved Kontor for militærmedisinsk epidemiologi i Forsvarets sanitet.

Forfatter har fylt ut ICMJE-skjemaet og oppgir ingen interessekonflikter.

Dag Hjelle (f. 1959) er spesialist i samfunnsmedisin, brigader/sjef for Medisinsk avdeling i Forsvarets sanitet og faglig ansvarlig for de medisinske tjenestene i Forsvaret.

Forfatter har fylt ut ICMJE-skjemaet og oppgir ingen interessekonflikter.

\section{Litteratur}

Norheim AJ, Mercer J. Medisinsk termografi alternativ diagnostikk? Tidsskr Nor Legeforen 2011; 131: 1758-9.

2. Tipton M. Lessons from history: morbidity of cold injury in the Royal Marines during the Falklands Conflict of 1982. Extrem Physiol Med 2013; 2: 24.

3. Imray C, Grieve A, Dhillon S. Cold damage to the extremities: frostbite and non-freezing cold injuries. Postgrad Med J 2009; 85: 481-8.

4. Golden FS, Francis TJ, Gallimore D et al. Lessons from history: morbidity of cold injury in the Royal Marines during the Falklands Conflict of 1982. Extrem Physiol Med 2013; 2: 23.

5. Gold JE, Cherniack M, Buchholz B. Infrared thermography for examination of skin temperature in the dorsal hand of office workers. Eur J Appl Physiol 2004; 93: 245-51.

6. Pauling JD, Shipley JA, Raper S et al. Comparison of infrared thermography and laser speckle contrast imaging for the dynamic assessment of digital microvascular function. Microvasc Res 2012; 83: $162-7$

7. Buzanello MR, Moro AR. Slaughterhouse workers exposed to cold: proposal of reference thermography values for hands. Work 2012; 41 (suppl 1): 2876-81

Mottatt 3.5. 2014, første revisjon innsendt 14.8. 2014, godkjent 20.8. 2014. Redaktør: Anne Kveim Lie.

Publisert først på nett. 